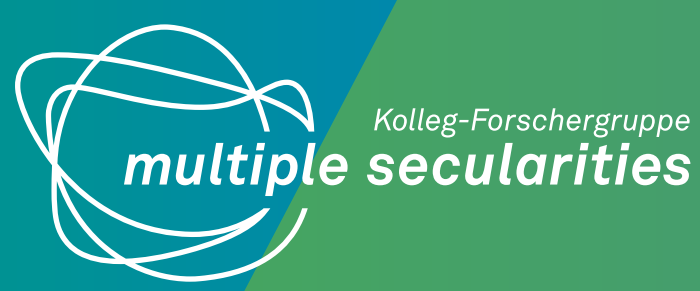

Monika Wohlrab-Sahr and Marian Burchhardt

\title{
Revisiting the Secular
} Multiple Secularities and Pathways to Modernity 
Working Paper Series of the HCAS "Multiple Secularities - Beyond the West, Beyond Modernities"

\#2: Monika Wohlrab-Sahr, and Marian Burchardt. "Revisiting the Secular: Multiple Secularities and Pathways to Modernity"

Leipzig, September 2017

(C) Leipzig University, HCAS „Multiple Secularities - Beyond the West, Beyond Modernities"

The HCAS is part of Leipzig University and funded by the German Research Foundation (DFG).

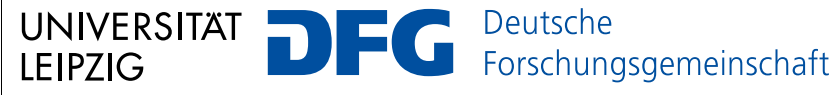


Monika Wohlrab-Sahr

Marian Burchhardt

\section{Revisiting the Secular}

Multiple Secularities and Pathways to Modernity 



\section{Contents}

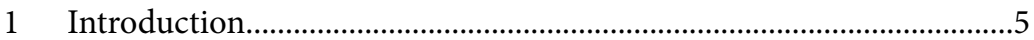

2 Religion, secularisation, and modernity...................................................

3 Multiple Secularities: The concept..........................................................12

3.1 Conceptual clarifications: Secularity, secularism,

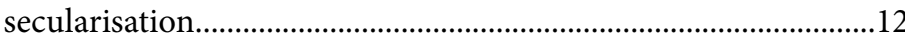

3.2 Paths of secularisation and varieties of secularism:

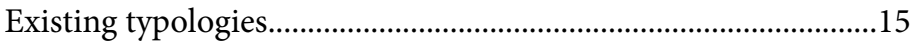

3.3 From 'multiple modernities' to 'multiple secularities'.....................17

3.4 Some remarks on the use of ideal-types...........................................19

3.5 Multiple Secularities: problems and solutions.................................20

4 Conclusions: Explaining secular hegemonies.........................................24

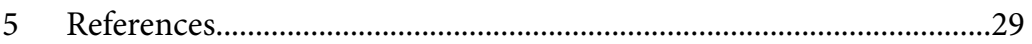




\section{Revisiting the Secular}

\section{Introduction}

For the last few decades, sociological debates about religion and secularisation have been characterised by confrontation between (often American) critics and (mostly European) defenders of secularisation theories. There has also been a remarkable rise in academic and public debates about the role of secularism in political regimes and in national as well as civilisational frameworks. These debates are shaped by the context of the changing position of the West in world politics, Islamist terror and the war on terror, struggles of religious minorities for recognition and influence, and the concomitant negotiations over the place of religion in the public sphere, as well as the emergence of post-national citizenship. Contributions from political theory, social anthropology and religious studies that emerged from this context have enriched the debate, but also contributed to fragmenting existing theories on the relationship between religion and modernity. Whereas scholars previously aimed to develop 'general theories' of secularisation that included deviations from the general model, newer approaches tend to highlight the specificity of Western European developments as opposed to those in the rest of the world, and sometimes even highlight their incomparability.

Meanwhile, critical approaches in the study of secularism that follow Foucauldian genealogical methodology, as especially promoted by Talal $\mathrm{Asad}^{2}$ and his followers, have become something like a new mainstream in research on secularism. Such approaches seem to only allow the study of secular-religious distinctions as the outcome of colonial impositions of secular-religious divides of European origin, and with them their related theoretical concepts. From that perspective, it seems coherent to conclude that secular-religious distinctions are 'alien' to Non-European contexts and to favour holistic notions of Islam or Hinduism as 'ways of life'. However, in many respects we consider this - perhaps unintended - consequence of

1 This paper is a revised (partly expanded, partly shortened) version of an earlier article that appeared in Comparative Sociology in 2012 (Monika Wohlrab-Sahr, and Marian Burchardt (2012), "Multiple Secularities: Toward a Cultural Sociology of Secular Modernities," Comparative Sociology 11/ 6.

2 Talal Asad (2003), Formations of the Secular: Christianity, Islam, modernity. (Stanford: Stanford University Press). 
approaches that started out as 'critical', a dead-end street for the social scientific study of religion. The basic premise underlying studies of secularisation, namely the search for the boundaries of religion and for their origin, as well as for the distinctions and differentiations between religion and its conceptual and institutional opposites ${ }^{3}$, is at risk of being 'thrown out with the bathwater' of classical secularisation theory. Against that backdrop, this article presents the conceptual framework of 'multiple secularities' with a view to refocusing sociological research on religion and its other. We suggest that this framework stimulates new ways of theorising the relationship between religion and secularity not only in the modern West, but also before modernity and beyond the West. ${ }^{4}$ In order to make visible what we regard as the foundational effect of secular dynamics, namely the social construction of the boundaries of religion, we pursue a strictly analytical understanding of secularity. This social construction is the outcome of contestations over the ways in which religion is culturally defined, socially and legally delimited, politically regulated and spatially as well as temporally arranged. Such analytic understanding does not prevent us from analysing the empirical normativity of such boundary drawing. Empirically, secularity is not a neutral issue, but bears normative imprints. ${ }^{5}$ Therefore, we conceptualise 'secularity' not only in terms of the making of conceptual distinctions and the institutionalisation of differentiation between religion and other societal spheres and practices, but also in terms of the cultural meanings underlying these distinctions and differentiations. Building on Max Weber, we distinguish between four basic ideal-types of secularity

3 In this article, we distinguish - thanks to a suggestion by Philip Clart - between conceptual distinctions (between the secular and the religious, for example) and practical, especially institutionalised differentiations. Which forms and terminology they may exist in, and in which relation they stand to each other, is an empirical question.

4 This article draws upon several research contexts. The concept of Multiple Secularities was originally developed in a research project with the same title at the Leipzig University (2011-2012), funded by the Saxon Ministry of Culture and Fine Arts. In the meantime, an interdisciplinary Humanities Centre for Advanced Studies Multiple Secularities: Beyond the West, Beyond Modernities has commenced work at the Leipzig University, exploring the applicability of the concept on pre-modern societies such as pre-modern Japan (Kleine, Christoph (2013), "Religion and the Secular in Premodern Japan from the Viewpoint of Systems Theory," Journal of Religion in Japan 2/1: 1-34). The Centre is funded by the German Research Foundation (DFG), and its directors are Christoph Kleine and Monika Wohlrab-Sahr. For further information, see: http://www.multiplesecularities.de.

5 Monika Wohlrab-Sahr (2011), "Multiple secularities and their normativity as an empirical subject: The Immanent Frame." 9 September 2017, last accessed. http://blogs.ssrc.org/ tif/2011/12/13/multiple-secularities-and-their-normativity-as-an-empirical-subject. 
that are related to specific reference problems and associated with specific guiding ideas.

\section{Religion, secularisation, and modernity}

Over the past few decades, sociological debates have problematised longcherished assumptions of process theories in the social sciences, stimulated revisions and given rise to new approaches. This concerns the classical version of modernisation theory, with its assumptions regarding convergence and diffusion, as well as the theory of secularisation, which assumes that the worldwide spread of the concepts of the nation state, parliamentary democracy, the rule of law, the liberal market economy, and rational science would give rise to a similar model of social organisation, in which religion would be largely confined to the private domain. In addition, it seemed obvious that an increase in the economic standard of living and in existential security would go hand in hand with a reduction in religious participation and belief. ${ }^{6}$ Although these 'classical' variants of modernisation theory have not disappeared from the scene and can still claim a certain degree of plausibility, they have nevertheless lost the dominant status they once enjoyed.

A wide-ranging debate over classical modernisation theory was conducted among social scientists as well as historians. ${ }^{7}$ Within this controversy, the long-dominant position of the convergence theorists is increasingly being superseded by approaches that assume different developmental paths as a permanent feature; these include authors who had initially proceeded on the basis of strong convergence assumptions. ${ }^{8}$ The new orientation has found prominent expression in the debate over 'multiple modernities. This approach defends a minimal, unifying concept of modernity but simultaneously recognises the enduring diversity of developmental paths. ${ }^{9}$ The divergence of historical pathways is assumed to be an outcome of different Axial Age cultures as well as of particular histories of interaction and encounters with the Western concept of modernity. ${ }^{10}$ It was the rapid

6 Ronald Inglehart (1997), Modernization and Postmodernization: Cultural, Economic and Political Change in 43 Societies (Princeton: Princeton University Press).

7 Peter Wagner (2001), Theorising modernity: Inescapability and Attainability in Social Theory (London: Sage); Wolfgang Knöbl (2007), Die Kontingenz der Moderne: Wege in Europa, Asien und Amerika (Frankfurt am Main, New York: Campus).

8 Ronald Inglehart, and E. W. Baker (2000), "Modernization, Cultural Change, and the Persistence of Traditional Values," American Sociological Review 65: 19-51.

9 Shmuel N. Eisenstadt (2000), „Multiple Modernities, “ Daedalus 129: 1-29.

10 Jóhann P. Árnason, Shmuel N. Eisenstadt and Björn Wittrock, eds. (2005), Axial Civiliza- 
economic and political rise of the 'Asian tiger' economies (Singapore, Hong Kong, South Korea), as well as China, India, and Brazil, in particular, that contributed to the belated recognition of the modernity of these societies by (Western) sociology and unsettled the hitherto prevalent identification of modernity with Western civilisation.

However, these developments have led only a few authors to reject the concept of modernity altogether. A parallel development can be observed in the discussion regarding secularisation. Although here attempts were made from early on to identify different paths of secularisation, these were initially motivated by the intention to develop a 'general theory of secularisation $^{\text {'11 }}$ and establish the conditions for exceptions to the general model. In the meantime, however, scholars of secularisation have also become aware of enduring differences ${ }^{12}$ and have emphasised the need to historicise the secularisation debate. ${ }^{13}$ In a different strand of the debate, the paradigm of secularisation was increasingly interpreted as a modern myth (principally inspired by the West) that, like the classical modernisation theory, is based on cultural biases and is unsuited to analyses beyond the Western world. ${ }^{14}$ It was argued that there were forms of modernity that can dispense not only with democracy and a liberal market economy but also with secularisation.

Concerns regarding the variety of secularisation were condensed by Casanova ${ }^{15}$ into a fundamental critique of the theoretical idea that three rather distinct sub-theses - functional differentiation, the decline of subjective religiosity, and the privatisation of religion - are necessarily linked. While Casanova initially still regarded functional differentiation as an indispensable component of secularisation, in his more recent work he has increasingly characterised this, too, as a genuinely Western development in the light of European history and its confrontations between temporal and

tions and World History (Leiden: Brill).

11 David Martin (1978), A General Theory of Secularization (Oxford: Blackwell).

12 David Martin (2005), On Secularization: Towards a Revised General Theory (Aldershot: Ashgate); Philip S. Gorski, and Ateş Altınordu (2008), “After Secularization?", Annual Review of Sociology 34: 55-85.

13 Philip S. Gorski (2000), "Historicizing the secularization debate: Church, state and society in late medieval and early modern Europe, ca. 1300-1700," American Sociological Review 65: 138-67.

14 One of the first to speak of secularisation as a 'myth' of modern societies within the context of European sociology of religion was Thomas Luckmann (1980), "Säkularisierung - ein moderner Mythos," in Lebenswelt und Gesellschaft: Grundstrukturen und geschichtliche Wandlungen (Paderborn: Ferdinand Schöningh).

15 José Casanova (1994), Public Religions in the Modern World (Chicago: University of Chicago Press). 
sacred authority, and has questioned its relevance for other regions and religions. ${ }^{16}$

In his book 'A Secular Age' ${ }^{17}$, Charles Taylor takes the critique further by arguing that secularisation theories have mainly been 'subtraction stories', based on the idea that secularisation unfolds as the liberation from earlier forms of knowledge whereby human nature is ultimately revealed. Like Casanova, Taylor distinguishes between secularity as the retreat of religion from public space and as the decline of beliefs, but ultimately focuses on secularity as a change in the 'conditions of belief' ${ }^{18}$ in terms of the emergence of exclusive humanism. Taylor is aware of and supports the idea of multiple modernities, stressing that "secularity, like other features of 'modernity'[,] [...] find[s] rather different expression, and develop[s] under the pressure of different demands and aspirations in different civilizations." ${ }^{\prime 19}$ But he self-consciously limits his analysis to the internal transformations of Christendom whereby belief in God is perceived as one option among others. While Taylor employs a unified idea of 'the West', others have limited the geographical validity of secularisation theory even further through the concept of 'European exceptionalism.' ${ }^{20}$

In recent years, empirical analyses have been increasingly shifting toward comparisons between 'secularisms ${ }^{21}$, i.e. the institutionalised and legally codified relationships between politics and religion, based on some kind of separation between the two spheres. In the case of Europe, for example, a distinction is made between formal establishment combined with pluralism (as in Great Britain), a cooperation model (as in Germany), and strict separation (as in the case of French laïcité). ${ }^{22}$ Other studies

16 José Casanova (2008), "Public religions revisited," in Religion: Beyond a Concept. Ed. Hent de Vries (New York: Fordham University Press), 101-19.

17 Charles Taylor (2007), A Secular Age (Cambridge: Belknap Press of Harvard University Press), 22.

18 Ibid., 12.

19 Ibid., 21.

20 Peter L. Berger (1999), The Desecularization of the World: Resurgent Religion and World Politics (Washington DC: Ethics and Public Policy Center); Peter L.Berger, Grace Davie, and Effie Fokas, eds. (2008), Religious America, Secular Europe? ATheme and Variations (Aldershot: Ashgate).

21 Linell E. Cady, and Elizabeth S. Hurd (2010), "Comparative Secularisms and the Politics of Modernity: An Introduction," in Comparative Secularisms in a Global Age. Ed. Linell E. Cady, and Elizabeth S. Hurd (New York: Palgrave Macmillan), 3-24.

22 Matthias Koenig (2007), "Europäisierung von Religionspolitik: Zur institutionellen Umwelt der Anerkennungskämpfe muslimischer Migranten," in Konfliktfeld Islam in Europa. Ed. Monika Wohlrab-Sahr, and Levent Tezcan. Special issue, Soziale Welt 17: 347-68. 
distinguish between assertive and passive secularisms, ${ }^{23}$ represented, for instance, by France and Turkey, on the one side, and by the United States on the other. Overall, however, the literature on secularism does not distinguish institutional separation systematically from the accompanying ideologies. Accordingly, secularism is often viewed primarily from the perspective of the critique of ideology. ${ }^{24}$

This has become especially influential in the work of Talal Asad ${ }^{25}$, who has focused his research on secularism on the genealogy of the secularreligious divide, which - in a process of co-constitution - produces religion and the secular at the same time. As this divide originates in the Christian hemisphere and has been imposed on non-Christian environments, mainly in the course of colonial encounters and processes of nation state formation, it is - according to this school of thought - inextricably linked to power and violence. While welcoming the attempt to trace back the history of concepts and its implications, we think that this approach bears the risk of insinuating that there was nothing similar to secular-religious distinctions and differentiations in non-Western contexts before the advent of Western modernity. It therefore de facto fosters holistic notions of the nonWestern, non-Christian world. Secularity is then the original sin which brings divide into the wholeness. The power and violence linked to politics that draw on such notions of wholeness and 'way of life', as for instance in the Hindutva movement or radical Islamism, are then either ignored or interpreted as defensive reactions against colonialism.

The critique of classical secularisation theory can be condensed into three fundamental objections. These concern (a) its alleged universalism, (b) its underlying process theory, and (c) its modernist normative bias. Overall, however, these critiques themselves are highly normative. While the secularisation paradigm is often considered to be Eurocentric and antireligious, recent research generally fashions itself as sympathetic toward religion. ${ }^{26}$ At times, the studies evoke the impression of a 'natural' religios-

23 Ahmet T. Kuru (2009), Secularism and State Policies toward Religion: The United States, France, and Turkey (Cambridge, New York: Cambridge University Press).

24 Tariq Modood (2010), "Moderate Secularism, Religion as Identity and Respect for Religion," The Political Quarterly 81/1: 4-14; Saba Mahmood (2006), "Secularism, Hermeneutics, and Empire: The Politics of Islamic Reformation," Public Culture 18/2: 323-47; Veit, Bader (2007), Secularism or Democracy? Associational Governance of Religious Diversity (Amsterdam: Amsterdam University Press).

25 Asad (2003), Formations of the Secular.

26 An exception is the book by Susan Jacoby (2004), Freethinkers: A history of American Secularism (New York: Metropolitan Books) in which the history of American secularism is related as the history of a liberation movement and of its coalition with religious 
ity among the population and of an ideological secularism founded on an alliance between political and academic elites. Compared to the older debate, recent contributions often engender an inversion of the subject and object of the critique: Whereas secularism used to be regarded as a means of liberation from the constraints of traditional and religious authority, religion now appears as a space of freedom, and secularism as an instrument of regimentation and of exclusion. The heightened awareness of secularism's articulation of power relationships and knowledge regimes, and its selective authorisation of forms of religious subjectivity and expression that are compatible with liberal modernity, is significant. However, such an awareness becomes flawed when it downplays the role of the autonomy associated with modernity and secularity, compared to that of moments of domination, as well as when it defines modernity in a manner that excludes religious freedom.

The critique of secularisation theory has certainly increased sensitivity to cultural differences and unjustified generalisations. However, there is now a danger of an essentialism of historically and culturally 'unique' constellations and undue generalisations about the ideological power of Western secularism. Given this situation, we think that the discussion of secularisation in sociology could be profitably linked to recent debates in the theory of modernity, in particular to the 'multiple modernities' approach and to the perspectives of cultural sociology. The 'multiple modernities' approach insists on the indispensability of the concept of modernity, but without persisting in its one-sided orientation to a seemingly universalistic Western model. Focusing on the intertwinements of universality and difference, it contends that all modern societies have been confronted with the European model. These confrontations and their interpretations, however, reflect specific - in Eisenstadt's terminology 'civilisational' - histories. As a consequence, the results have differences that cannot sufficiently be explained by processes of diffusion and convergence.

This also implies that variations across time and space in how the religioussecular divide is understood and justified cannot be reduced to structural and institutional dimensions. Against the tendency to construe this divide mainly in terms of relationships between church and state, we suggest that cultural sociology, with its insistence on the ineluctable embeddedness of action in horizons of affect and meaning, ${ }^{27}$ can offer new insights into

dissenters - for example, in the controversies over the American Constitution.

27 Jeffrey Alexander, and Philip Smith (2002), "The Strong Program in Cultural Theory: Elements of a Structural Hermeneutics," in Handbook of Sociological Theory. Ed. Jonathan H. Turner (Boston: Springer Science), 136; Thomas Schmidt-Lux, Monika Wohlrab-Sahr, 
the endurance of variations and the persistency with which they are defended. This is not meant to substitute institutional approaches. Rather, we consider institutional regulations to be one expression of 'cultures of secularity'. We suggest the conceptualisation of both dimensions by asking which societal reference problems the development of different forms of secularity responds to and what solution the different forms of secularity offer for these problems.

\section{$3 \quad$ Multiple Secularities: The concept \\ 3.1 Conceptual clarifications: Secularity, secularism, secularisation}

The dominant concepts in the current international debate are secularisation and secularism. Until now, the concept of secularity has only seldom featured centrally. ${ }^{28}$ Whereas the concept of secularisation is used primarily in sociological process models addressing processes of functional differentiation, religious decline, and privatisation of religious practice, secularism refers to the arrangements of the institutional separation of politics/the state and religion as well as to their ideological legitimisations.

In what follows, we propose to reserve the concept of secularism for the ideological-philosophical programme - hence, for the explicit ideology of separation - and related political practices, and the concept of secularity, by contrast, for the cultural and symbolic distinctions, as well as institutionally anchored forms and arrangements of differentiation between religion and other social spheres. Following Asad ${ }^{29}$, we assume that both spheres are first identified as religious and secular domains in the course of their distinction and differentiation. We also assume that in many regions, however, the history of such distinction and differentiation may have started much earlier than the use of the terminology of the secular suggests. ${ }^{30}$ It is an open empirical question as to when this originates and which terminology has been used to

and Alexander Leistner (2016), eds., Kultursoziologie: Eine problemorientierte Einführung (Weinheim: Beltz), 29-48.

28 Asad (2003), Formations of the Secular; Taylor (2007), A Secular Age; Berger, Davie, and Fokas (2008), Religious America, Secular Europe?

29 Asad (2003), Formations of the Secular.

30 For Japan, see Christoph Kleine (2013), "Religion and the Secular in Premodern Japan from the Viewpoint of Systems Theory," Journal of Religion in Japan 2/1: 1-34 and (2013), "Religion als begriffliches Konzept und soziales System im vormodernen Japan: Polythetische Klassen, semantische und funktionale Äquivalente und strukturelle Analogien," in Religion in Asien? Studien zur Anwendbarkeit des Religionsbegriffs. Ed. Peter Schalk et al. (Uppsala: Uppsala Universitet), 225-92. 
designate the areas and practices that have been distinguished.Secularisation signifies both the process of differentiation, including diminishing mutual influences between religion and other social domains, and the decline in religious participation and belief. ${ }^{31}$

The concept of secularity is therefore more inclusive than that of secularism and also encompasses the, at times latent, taken-for-granted forms of the distinction between the religious and the non-religious. In addition, we expressly do not confine analysis to the relationship between the state and religion but include other functional domains of society (for instance, those of law, education, science, business, etc.), as well as everyday life and the public sphere. The connections between such religious-secular distinctions and their legitimating guiding ideas differ case by case. One can assume that the corresponding divisions develop a special cultural dynamic where they are not only implicitly practised but are made explicit and become condensed into guiding ideas, as was also the case with the guiding ideas of modernity and progress or with the 'social projections ${ }^{32}$ that went along with the introduction of new technologies, such as letterpress printing. Exploring secularity in terms of symbolic distinctions and institutional differentiations implies, of course, that religion and the non-religious are far from being completely separate, without any points of contact or mutual entanglements. Recent anthropological literature ${ }^{33}$ sometimes mistakenly claims that secularisation theory propagated the complete separation of religion from other social spheres. This misunderstanding obviously rests on the conflation of secularisation theory and the secularist self-image prevalent among various social groups in which concepts of separation circulate as political ideologies. In contrast to such selfimages, sociological ideal-types always assume a variety of combinations of religion, national politics, and the claims of religious groups and secular agents carried into the public sphere. Secularity is then considered as a result of social conflicts ${ }^{34}$ or negotiation processes. Far from refuting the concept of the religious-secular divide, the entanglements of religion and

31 Casanova (1994), Public Religions in the Modern World.

32 Michael Giesecke (2006), Der Buchdruck in der frühen Neuzeit: Eine historische Fallstudie über die Durchsetzung neuer Informations- und Kommunikationstechnologien. (Frankfurt am Main: Suhrkamp), 156.

33 Mahmood (2006), "Secularism, Hermeneutics, and Empire“.

34 Monika Wohlrab-Sahr, Thomas Schmidt-Lux, and Uta Karstein (2008), "Secularization as Conflict," Social Compass 55/2: 127-39; Christian Smith (2003), "Introduction: Rethinking the secularization of American public life," in The Secular Revolution: Power, interests, and conflict in the secularization of American public life. Ed. Christian Smith, (Berkeley: University of California Press) 1-95. 
politics must be viewed as areas in which the boundaries between religion and secular spheres are negotiated, challenged, and redrawn. For this reason, we agree with Casanova ${ }^{35}$ that the concepts of secularisation and secularity make sense "as an analytical framework for a comparative research agenda that aims to examine the historical transformations of all world religions under conditions of modern structural differentiation."

It also seems evident from this perspective that the rejection of concepts such as secularisation and secularism in large parts of the Islamic world is not necessarily bound up with the absence of differentiations between the religious and the secular, hence with the omnipresence of religion ${ }^{36}$. Our assumption is rather that there are no readily accessible guiding ideas of secularity with which such distinctions could be legitimised. ${ }^{37}$ In addition, Islam is also widely considered a cultural identity, especially in the Arab world with its history of belated nation-state formations. This blurring of the boundaries of religion and culture renders a positive articulation of secularity extremely difficult. Correspondingly, the most intransigent resistance to (Western) secularism is also articulated by Muslim groups active in the transnational arena. By contrast, secularity was part, though only at times, of the self-image of the more 'robust' nation-states, such as Syria or Iraq under the Baath regime. Here it must be stated, however, that especially among Iranian Muslim intellectuals, some living abroad, some still in Iran, there have recently been strong contributions arguing for the limitation of the scope of religion. This limitation has variously concerned the autonomy of a democratic political sphere, the freedom of the individual, the independence of rationality from religion, or the autonomy of personal spiritual orientation independent of institutionalised religion. ${ }^{38}$ The term 'secularity' may be used or not in these

35 José Casanova (2006), "Secularization Revisited: A Reply to Talal Asad," in Powers of the Secular Modern: Talal Asad and his Interlocutors. Ed. David Scott and Charles Hirschkind (Stanford: Stanford University Press), 19.

36 See Schulze, Reinhard (2010), "Die Dritte Unterscheidung: Islam, Religion und Säkularität: Säkularität unter Muslimen," in Religionen - Wahrheitsansprüche - Konflikte: Theologische Perspektiven. Edited by Walter Dietrich, and Wolfgang Lienemann (Zürich: TVZ). 147-206.

37 Daniel Kinitz (2015), "Deviance as Phenomenon of Secularity: Islam and Deviants in Twentieth-century Egypt-A Search for Sociological Explanations," in Multiple Secularities Beyond the West: Religion and Modernity in the Global Age. Ed. Marian Burchardt, Monika Wohlrab-Sahr, and Matthias Middell (Boston: De Gruyter), 97-119.

38 Soroush, Abdolkarim (2000), Reason, Freedom, and Democracy in Islam: Essential Writings of Abdolkarim Soroush. Ed. Mahmoud Sadri, and Ahmad Sadri (Oxford: Oxford University Press; Akbar Ganji (2008), The Road to Democracy in Iran (London: Boston Review Books); Mohammad M. Shabestari, and Jan Kuhlmann (2012), "Interview with Mohammad Mojtahed Shabestari: Why Islam and Democracy Go Well Together." 
writings, but the differentiation between religion and other societal spheres and practices is explicitly addressed, and notions of a privatised, spiritualised religiosity go along with such differentiation.

In many other cases, however, the history of the resonance between the Western and the Islamic world is reflected primarily in the negative relationship to a form of secularity perceived as ideological secularism which is associated with hostility to religion and atheism. This does not preclude, however, de facto differentiations in the areas of education, science, business, law, and politics, where these are often subordinated to references to Islam or the sharia. Therefore, we argue against a reading of Islamic societies which sees their path to secularisation (in particular to functional differentiation) as being obstructed primarily by intrinsic features of Islam. More relevant, it seems to us, is the interplay between religious-cultural particularity and histories of resonance whereby the possibilities of explicitly adopting secular ideas are undermined, as well as existing power relationships in the Islamicate world. We would therefore also argue against a holistic reading of Islam as a 'way of life', with regard to which the perspective of secularity is per se considered inapplicable. ${ }^{39}$ This holistic notion of Islam that perpetuates its indivisibility and sometimes even extends this to an anthropological concept of 'homo Islamicus' as opposed to 'Western $\operatorname{man}^{\text {'40, }}$, is not less ideological than modernist concepts of the inevitability of secularisation have been. The analytical distinction between ideologies of separation and practices of differentiation also opens our eyes to pre-modern practices that provide intellectual resources, and thereby pave the way for modern forms of secularity, ${ }^{41}$ without themselves already being associated with secular guiding ideas.

\subsection{Paths of secullarisation and varieties of secullarism: Existing typologies}

Although research on secularisation and secularism entails comparative methods and typologies, they represent only a minor part of the literature.

https://en.qantara.de/content/interview-with-mohammad-mojtahed-shabestari-whyislam-and-democracy-go-well-together, last accessed 1 June 2017; Laura Secor (2016), Children of Paradise: The Struggle for the Soul of Iran (New York: Riverhead Books).

39 John L. Esposito, and Azzam Tamimi (2000), Islam and Secularism in the Middle East (London: Hurst \& Company).

40 Parvez S. Manzoor (2000), "Descralising Secularism," in Islam and Secularism in the Middle East. Ed. John L. Esposito, and Azzam Tamimi (London: Hurst \& Company), 96.

41 Rajeev Bhargava (2010), "The 'Secular Ideal' before Secularism: A Preliminary Sketch," in Comparative Secularisms in a Global Age. Ed. Linell E. Cady, and Elizabeth S. Hurd (New York: Palgrave Macmillan), 159-80; Kleine (2013), "Religion als begriffliches Konzept". 
Comparisons between the United States and Europe or between different European societies have been the primary focus of attention to date in both the sociology of religion and historiography ${ }^{42}$ with institutional arrangements of the relationship between religion and the state being scrutinised as both independent and dependent variables. ${ }^{43}$ Koenig ${ }^{44}$ as well as Fetzer and Soper ${ }^{45}$ examine the importance of institutional arrangements for regimes incorporating religious minorities and challenges for principles of citizenship. $^{46}$

The origins of such regimes are often explained, in turn, on the basis of specific historical dynamics, in particular the relationships between temporal and religious rule in earlier historical phases, traditions of political thought, and the characteristics of the dominant religious traditions. Thus, in an attempt at sociological mapping, Martin ${ }^{47}$ differentiates models of religious monopoly, duopoly, and pluralism and specifies Protestant, Catholic, and orthodox scenarios, respectively, which in turn undergo a variety of reconfigurations at the subnational level as regards the relationship between political-theological centres and peripheries. Similarly, Casanova ${ }^{48}$ explores the differences between a Protestant, primarily Anglo-Saxon-Calvinist path, and a French-Latin-Catholic path.

Demerath $^{49}$ presents one of the few sociological typologies that is explicitly global in scope and also addresses dynamics of imperialism, colonialism, and decolonisation in an incipient way. He differentiates between directed and undirected scenarios, and between internal and external sources of secularisation.

Whereas the above-mentioned approaches make efforts to connect so-

42 Hugh McLeod (2007), The Religious Crisis of the 1960s (Oxford, New York: Oxford University Press).

43 Berger, Fokas, and Davie (2008), Religious America, Secular Europe?; Rodney Stark, and Roger Finke (2000), Acts of Faith: Explaining the Human Side of Religion (Berkeley: University of California Press).

44 Koenig (2007), "Europäisierung von Religionspolitik".

45 Joel S. Fetzer, and J. C. Soper (2005), Muslims and the State in Britain, France, and Germany. Cambridge studies in social theory, religion, and politics (Cambridge, UK: Cambridge University Press).

46 The regimes are: formal establishment with simultaneous pluralism implemented at low thresholds; corporatist cooperation between the state and religious actors; and laïcité.

47 Martin (1978), A General Theory of Secularization; Martin (2005), On Secularization: Towards a Revised General Theory.

48 José Casanova (2009), “The Secular and Secularisms," Social Research 76/4 : 1049-66.

49 N. J. Demerath (2007), "Secularization and Sacralization Deconstructed and Reconstructed," in The SAGE Handbook of the Sociology of Religion. Ed. James A. Beckford, and N. J. Demerath (Los Angeles: Sage), 71. 
cial dynamics of secularisation with regimes of secularism, typologies from the field of comparative politics often have a more descriptive orientation and are restricted to institutional arrangements. Many approaches connect descriptive typologies with normative questions. $\mathrm{Kuru}^{50}$ compares 'assertive' and 'passive' secularisms, whereas Modood ${ }^{51}$ - similarly - juxtaposes 'moderate' and 'radical' secularisms. Stepan ${ }^{52}$ examines forms of 'twin tolerations,' by which he understands mutual concessions of autonomy on the part of religious and state actors. Taken as a whole, the achievement of this research tradition consists in bringing together a multitude of different state norms, discourses, and practices under the framework of models. However, its almost complete lack of attention to the everyday perspectives and the culturally saturated imaginaries of social groups imply that the cultures of secularity that develop under certain conditions beyond the reach of state guidelines are hardly addressed or are taken as mere effects of state policy. For the purposes of a cultural sociology of secularity, this cannot be sufficient. When we talk of 'cultures of secularity', we refer to the meaning that is attached to the institutions, practices or discourses of differentiation and distinction with regard to religion.

Moreover, recent research has failed to construct ideal-types of secularity in Weber's sense..$^{53}$ Although Eisenstadt's work on multiple modernities has identified numerous fault lines and antinomies, he did not condense them into ideal-types.

\subsection{From 'multiple modernities' to 'multiple secularities'}

While inspired by the idea of 'multiple modernities', our conceptualisation remains distinct from its strong 'civilisational' underpinning and its projections upon the ancient pasts of these civilisations. ${ }^{54}$ Research into multiple modernities has mostly tried to collect evidence on axial age cultures ${ }^{55}$ or

50 Kuru (2009), Secularism and State Policies toward Religion.

51 Modood (2010), "Moderate Secularism, Religion as Identity and Respect for Religion".

52 Alfred Stepan (2000), "Religion, Democracy, and the 'Twin Tolerations." Journal of Democracy 11/4: 37-57.

53 Max Weber (1985), "Die 'Objektivität' sozialwissenschaftlicher und sozialpolitischer Erkenntnis," in Gesammelte Aufsätze zur Wissenschaftslehre. Ed. Johannes Winckelmann (Tübingen: Mohr).

54 Peter Wagner (2005), "Palomar's Questions: The Axial Age Hypothesis, European Modernity and Historical Contingency," in Axial Civilizations and World History. Ed. Jóhann P. Árnason, Shmuel N. Eisenstadt and Björn Wittrock (Leiden: Brill), 95.

55 Shmuel N. Eisenstadt (2002), "The First Multiple Modernities: Collective Identities, Public Spheres and Political Order in the Americas," in Globality and Multiple Modernities: Comparative North American and Latin American perspectives. Ed. Luis Roniger, and 
their non-axial counterparts ${ }^{56}$ and to elaborate on their consequences for the formation of collective identities. ${ }^{57}$ In general, Eisenstadt's civilisational approach tends to identify the cultural foundations of collective identities rather than constructing ideal-types for the purpose of empirical comparison. It would be too strong an assumption, however, to identify the 'cultures of secularity' with collective identities based on 'civilisations'. Moreover, the idea of 'multiple secularities' captures not simply a consequence of an ancient past, but the interplay of cultural histories and modern encounters. While being a core assumption of Eisenstadt's work, studies building on him focus on past origins rather than on present interplays. With a view towards secularity, such interplays are key, in that at least the explicit public usage of secular-religious distinctions is hardly perceivable without some sort of encounter with European forms of modernity. Most of the studies on multiple modernities remain highly abstract and their empirics and connections to present conflicts are rather vague. Against this backdrop, our goal is to enable the interpretation of recent conflicts by taking cultural histories and historic entanglements into account.

However, there are important similarities between our ideal-types of secularity and Eisenstadt's notion of Axial Age civilisations. One of the central features of the latter is the emergence of strong notions of transcendence and the separation of mundane and transcendental spheres. ${ }^{58}$ It should be emphasised that modern secular-religious distinctions fully depend on older differentiations between mundane and transcendent spheres, even if the former are generally more closely associated with the history of medieval Christian Europe. More research is needed into the conditions under which Axial Age notions of transcendence feed into concepts of secularity in the way suggested in this paper. Overall, we agree with the multiple modernities approach in its insistence on the plurality of cultural paths

Carlos H. Waisman (Brighton: Sussex Academic Press), 7-28; Shmuel N. Eisenstadt (2005), "Axial civilizations and the Axial Age Reconsidered," in Axial Civilizations and World History. Ed. Jóhann P. Árnason, Shmuel N. Eisenstadt and Björn Wittrock (Leiden: Brill), 53164; Kurt A. Raaflaub (2005), "Polis, 'the Political', and Political Thought: New Departures in Ancient Greece, c. 800-500 BCE," in Axial Civilizations and World History. Ed. Jóhann P. Árnason, Shmuel N. Eisenstadt and Björn Wittrock (Leiden: Brill), 253-83.

56 Shmuel N. Eisenstadt (1996), Japanese Civilization: A Comparative View (Chicago: University of Chicago Press).

57 Shmuel N. Eisenstadt (1998), "The Construction of Collective Identities in Latin America: Beyond the European Nation-State Model," in Constructing Collective Identities and Shaping Public Spheres: Latin American Paths. Ed. Luis Roniger, and Mario Sznajder (Brighton: Sussex Academic Press), 245-63.

58 Björn Wittrock (2005), "Meaning of the Axial Age," in Axial Civilizations and World History. Ed. Jóhann P. Árnason, Shmuel N. Eisenstadt, and Björn Wittrock (Leiden: Brill), 66. 
into modernity and on the effects of a history of mutual entanglements in which the European modernity plays the role of a (positive or negative) point of reference. Both aspects are of specific importance for the issue of secularity.

To sum up, what distinguishes the approach presented here from the ones mentioned above is that: (a) it attempts to develop ideal-types of secularity in a way that supports work on concrete historical cases, while taking into account the distinction between these two tasks; (b) it seeks to overcome the separation between processes of secularisation (religious decline and functional differentiation) and figures of secularity (configurations of cultural meaning); (c) it relates the figures of secularity back to historical processes of and conflicts over secularisation; (d) through its focus on the cultural meaning of secularity, it avoids a restriction to state policy; and (e) it aims at a comparative interpretation of current religious controversies against the background of the conflicts transmitted by cultural memory.

\subsection{Some remarks on the use of ideal-types}

Importantly, one must not conflate the differences between ideal-types in the Weberian sense and specific national or regional variations. Ideal-types are analytical abstractions that are developed from empirical and historical data and mirrored back on them to guide the construction of hypotheses and theorisation. 'Real' configurations will always differ from ideal-types, but the latter help to better examine the former. Our goal is therefore to develop an analytical framework that allows comparative analysis of social change in regions, or nation-states or any other social formation. Thus, the construction of ideal-types is not an end in itself or an exercise in 'pure theory'. Rather, it is a guide to empirical work. Some empirical configurations that are analysed and 'compared' with the ideal-typemay come closer to it than others. In some cases, competing or contradictory tendencies rather than a unifying strand may be revealed; and in others, comparisons with the ideal-typical distinctions may help to develop hypotheses on the non-existence of certain features and their consequences rather than to subsume them into one of the types.

There are some limitations regarding the reach of our typology. Basically, it is not meant to comprehensively capture developments everywhere in the world. It is related to empirical cases where a 'guiding idea' of secularity, on which social groups can draw, was actually formulated. This implies that all the cases in which de facto differentiations between the religious and the secular exist, but remain implicit and are not expressed through guiding 
ideas, are not directly included in the model. Simultaneously, however, we suggest that diverging configurations too can be fruitfully discussed on the basis of the model and its analytical distinctions.

\subsection{Multiple Secularities: problems and solutions}

By 'multiple secularities', in what follows, we mean the forms of distinction and the institutionalisation of differentiations between the religious and other social domains (which are thereby marked as non-religious), that are, in part, legitimised through guiding ideas. We assume that these secularities exhibit different structures of meaning that document a specific social history of conflict no less than the competing influence of other forms of secularity.

We assume further that the 'multiple secularities' that are taking shape in different countries and regions 'respond' to specific societal problems (as their reference problems) and offer solutions to them. Obviously, these problems arise at some point and in some form in many societies, but they arise with different degrees of urgency at different points in time.

As a first approximation, we identify four such reference problems: (1) the problem of individual freedom vis-à-vis dominant social units, be they groups or the state; (2) the problem of religious heterogeneity and the resulting potential or actual conflictuality; (3) the problem of social or national integration and development; and (4) the problem of the independent development of institutional domains. It is clear that most of these problems are closely associated with the formation of modern societies and states and the ideas on which they are founded, whereas the second, at least, also arises in pre-modern societies. It is no accident that reflections on pre-modern sources of modern secularity generally begin here. One might, however, also find variations of the other reference problems in pre-modern societies, like the strengthening of a centralised power. ${ }^{59}$

It is clear that understandings and interpretations of such problems and solutions are often contested and, as a consequence, are collectively shared to varying degrees. What is considered a problem, for instance, with regard to nation-building and religious diversity, and a viable solution in terms of secularity, is therefore subject to processes whereby interpretations of problems and solutions are negotiated and authorised. These processes of authorisation, in which the dominant social meanings of religion and secularity impinge on one another, are thus invariably embedded in power relationships defining the deep strata of historical experience in a given society and its religious and po-

59 Kleine (2013), "Religion als begriffliches Konzept”. 
litical tradition.

Processes of definition and framing involve a variety of social and political actors and social movements, often with antagonistic agendas. Typically, however, the reference problems, and the guiding ideas epitomising them, can be used as reference points for a variety of groups, even if these groups pursue competing goals in other respects. The reference problems and solutions mentioned above, together with their associated guiding ideas, may therefore develop a binding social impetus, at least for certain historical periods, and thereby become points of crystallisation for collective identities. As a consequence, we can see the emergence of more or less entrenched 'cultures of secularity', which are shared across otherwise existing lines of difference. The four central problems outlined above provide motives for institutionalising differentiations between the religious and other social spheres. As latent motives and social practices, they can certainly coexist, whereas, as overt motifs, they tend to compete with each other. Our assumption is, however, that given certain preconditions, one of them will become dominant at least for a certain period by being aligned with guiding ideas that set the basic terms for distinguishing religious and secular spaces in a given society, and thereby push the other motives, at least at times, into the background. There is no doubt, however, that these motives are often highly contested. Accordingly, our claim is not that such a basic tenor of secularity can be identified in every society, or that just one of the motives matters. The following constellations may restrict such development:

a) Practices of differentiation may remain below the threshold at which guiding ideas are formulated. An example of this would be (parts of) the Islamicate world.

b) Different concepts of secularity may coexist and find support from equally strong groups. This is likely to be the case in situations where the urge to find solutions for specific societal problems is not very strong. It may also be the case in situations where the need to form coalitions is stronger than anything else. Times of constitution-building could be an example of that.

c) Different concepts of secularity and guiding ideas may compete with each other. This situation seems to exist in a whole range of countries. It is especially visible in postcolonial countries, for example in South Africa, or in Western societies during phases of transition. ${ }^{60}$

d) The guiding idea can be the ideology of elites that diverges from the

60 This was discussed in Cora Schuh, Marian Burchardt, and Monika Wohlrab-Sahr (2012), "Contested Secularities: Religious Minorities and Secular Progressivism in the Netherlands," Journal of Religion in Europe 5: 349-83. With regard to the Netherlands, where we see a shift from secularity centred on the accommodation of groups to a model that centres on national development and societal integration. 
dominant social practices of differentiation, as with the secularist reforms of Kemal Atatürk, which today are patently in conflict with the Islamic self-understanding of parts of the Turkish population and its present government.

e) Finally, it is also possible that the problems in question are not 'resolved' in the direction of secularity but through the imposition of religious authority, such that secularity remains in the background as a latent option.

Even if the distinction between four basic types of secularity is an idealtypical construction that is not identical to reality, we assume that a basic cultural understanding of secularity can be identified in a whole range of societies, at least in certain periods. During 'settled periods' ${ }^{61}$ this will remain latent but it will become manifest in periods of conflict. Such conflicts may be the expression of 'critical junctures' in Kuru's ${ }^{62}$ sense and trigger shifts in historical orientations. ${ }^{63}$ We have used the formula "secularity for the sake of..." to designate these basic patterns. At a first approximation, we distinguish between the following forms: (1) secularity for the sake of individual rights and liberties; (2) secularity for the sake of balancing/pacifying religious diversity; (3) secularity for the sake of societal or national integration and development; and (4) secularity for the sake of the independent development of functional domains of society. The identification of ideal-types is a process that shifts between the analysis of empirical cases, the attempt to condense them into theoretical relationships, the theoretically informed return to empirical cases and so on. ${ }^{64}$ Thus, it follows the pattern of maximal and minimal comparison. To start with the reference problems of societal and national integration, and the problem of individual rights and liberties, both of which can be considered a centralised focus ${ }^{65}$, raises questions about the opposite, a decentralised focus, in our case the reference problem of balancing group diversity, but also the problem of the independent development of functional domains. A second

61 Ann Swidler (1986), "Culture in Action: Symbols and Strategies," American Sociological Review 51/2: 278pp.

62 Kuru (2009), Secularism and State Policies toward Religion.

63 Kuru (2009), Secularism and State Policies toward Religion defined critical junctures as periods or moments in which both agency and structural conditions are available for systematic change.

64 In general, this comes close to the research strategy of the grounded theory methodology. Cf. Anselm L. Strauss (1987), Qualitative Analysis for Social Scientists (Cambridge: Cambridge University Press).

65 While not being 'centred' in the same way as the concepts of societal integration or national development, 'individual liberties' has the potential to be a unifying principle, especially in contrast to 'group rights', which are much more difficult to institutionalise and have a thrust that is de-centring rather than unifying. 
comparative perspective concerns questions regarding the definition of the social that is inherent to the formulation of the reference problem. Here, we can differentiate between definitions of the social that are derived from the life-world domain of people and the community, and others that are derived from societal and institutional perspectives. Here, definitions of the social based on life-world perspectives, such as that of individual liberties, may clash with 'systemic' definitions that are dominant in concepts of societal integration and national progress or the development of institutional domains.

These four basic forms of secularity are associated with different guiding ideas: in the first type, it is the idea of freedom ${ }^{66}$ and individuality; in the second, that of toleration, respect and non-interference; whereas the third type involves the ideas of progress and enlightenment; and the fourth, finally, involves the guiding ideas of rationality, efficiency, and autonomy. This leads us to the following four-field matrix:

\begin{tabular}{|c|c|c|c|}
\hline & Implicit & Focus \\
\hline & & Centralised & Decentralised \\
\hline \multirow{2}{*}{ 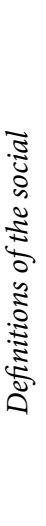 } & 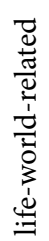 & $\begin{array}{l}\text { Typ 1: } \\
\text { Secularity for the sake of } \\
\text { individual liberties } \\
\text { Guiding ideas: freedom, } \\
\text { individuality }\end{array}$ & $\begin{array}{l}\text { Typ 2: } \\
\text { Secularity for the sake of } \\
\text { balancing/accomodating } \\
\text { diversity } \\
\text { Guiding ideas: toleration, } \\
\text { respect, non-interference }\end{array}$ \\
\hline & 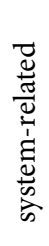 & $\begin{array}{l}\text { Typ 3: } \\
\text { Secularity for the sake of } \\
\text { social integration/national } \\
\text { development } \\
\text { Guiding ideas: progress, } \\
\text { enlightenment }\end{array}$ & $\begin{array}{l}\text { Typ 4: } \\
\text { Secularity for the sake of } \\
\text { independent development of } \\
\text { institutional domains } \\
\text { Guiding ideas: rationality, } \\
\text { efficiency, autonomy }\end{array}$ \\
\hline
\end{tabular}

66 Of course, the notion of freedom can also become the guiding idea of national development, the symbol of social progress and the preservation of social sovereignty. Examples of this can be found in the French Revolution, though also in the right-wing populist 'freedom parties', as, for example, in the Netherlands. 
We assume that the dominance of one reference problem tends to create tensions vis-à-vis the others not only in theoretical terms but also in the real world. For example, prioritising the balance between religious groups is likely to create tensions with regard to individual liberties, to the pursuit of national interests, as well as to guaranteeing the autonomy of functional domains. In a more abstract way, the emerging field of relationships and tensions can be depicted as follows:

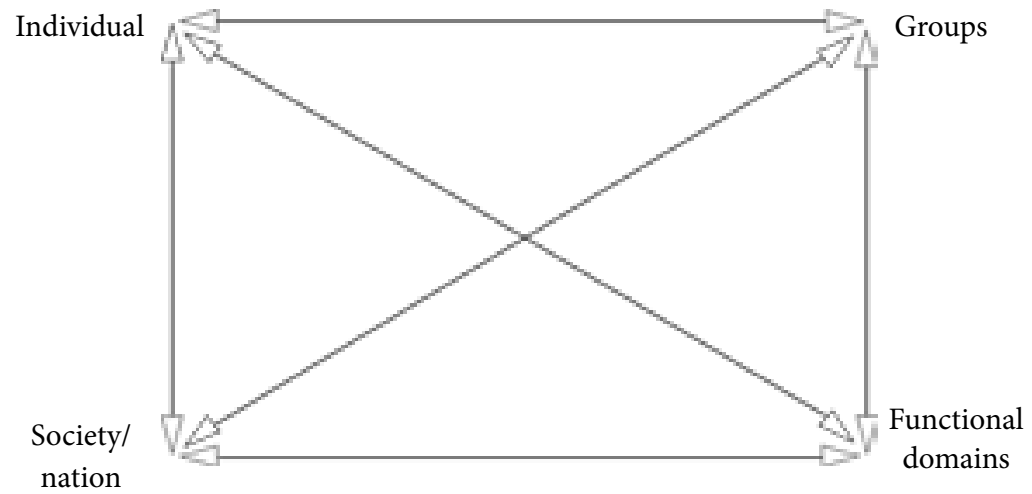

\section{Conclusions: Explaining secullar hegemonies}

What does it mean to say that a particular type of secularity becomes culturally dominant? Across the world, secular collective identities and institutions are seen to be under pressure from religious revitalisations. As such, in countries such as India ${ }^{67}$, Armenia ${ }^{68}$, and Turkey ${ }^{69}$, religious nationalism confronts secular nationalism and the secular state is also challenged, for instance with demands made by conservative Christians in the US and conservative Muslims in Europe. ${ }^{70}$ Again, however, we suggest that

67 Peter van der Veer (1994), Religious Nationalism: Hindus and Muslims in India (Berkeley: University of California Press).

68 Marian Burchardt, and Hovhannes Hovhannisyan (2016), "Religious vs secular nationhood: 'Multiple secularities' in post-Soviet Armenia," Social Compass 63/4: 427-43.

69 Yael Navaro-Yashin (2002), Faces of the State: Secularism and Public Life in Turkey (Princeton: Princeton University Press); Esra Özyürek (2006), Nostalgia for the Modern: State Secularism and Everyday Politics in Turkey. Politics, history, and culture (Durham: Duke University Press); Nilüfer Göle (2015), Islam and Secularity: The Future of Europe's Public Sphere (Durham: Duke University Press).

70 Christian Joppke (2015), The Secular State Under Siege: Religion and Politics in Europe and America (Cambridge: Polity Press). 
it is useful to distinguish between secularism and secularity. The political influence of the ideological programme of secularism may shift more or less quickly with new political parties coming to power. The cases of Turkey, Poland and Hungary show that religion-friendly political parties typically try to pass religion-friendly policies (especially if that is an essential part of their political identity), and thus to change regimes of political secularism. Such changes are often driven by nationalist parties which claim to represent the religious interests of the majority, and are typically inspired by the goal of reinforcing cultural homogeneity and hegemony. In other words, they aim to secure national unity not through institutionalising secularity but a national religion. By contrast, in societies where secularism has been transformed into an element of national identity as in Quebec for instance, ${ }^{71}$ non-nationalist, pluralistically oriented parties are typically more religion-friendly and promote policies that give greater space to religious expression.

At the same time, however, the ways in which secularity is legally codified and anchored in constitutional law often prove to be relatively stable and independent from such political shifts. ${ }^{72}$ Courts may employ and promote the language of secularism as a democratic value, or shy away from it for reasons of political expediency, and, in both instances, defend the same legal regulations of religion. Similarly, it is also clear that broader, culturally shared understandings of secularity are often disconnected from changes in the political regime of secularism. In other words, secularism and secularity move in different historical rhythms. The notion of post-secularism, while useful as a philosophical concept to describe a changed awareness of the contemporaneity of religion and reason in liberal democracies, ${ }^{73}$ has sometimes led scholars to conflate these differences. As Hjelm ${ }^{74}$ has argued, the new visibility of religion, in Europe and elsewhere, does not necessarily imply a new social significance of religion. New forms of religious diversity have certainly led scholars, politicians and intellectuals to question the adequacy of secularism as a regulatory political principle, but

71 Marian Burchardt (2016), "Recalling modernity: How nationalist memories shape religious diversity in Quebec and Catalonia," Nations and Nationalism 41/4: 1-21.

72 Matthias Koenig (2015), "Governance of Religious Diversity at the European Court of Human Rights," in International Approaches to Governing Ethnic Diversity. Ed. Jane Boulden and Will Kymlicka (Oxford: Oxford University Press), 51-78; Joppke (2015), The Secular State Under Siege.

73 Jürgen Habermas (2006), “Religion in the Public Sphere." European Journal of Philosophy 14/1: 1-25.

74 Titus Hjelm (2015), Is God back? Reconsidering the New Visibility of Religion (London, New York: Bloomsbury Publishing). 
this has not diminished but increased the analytical stakes of secularity. Moreover, as argued before, cultures of secularity play out on different levels. Secularity is codified in law, discursively constructed in the public sphere, and a part of the cultural habitus of individuals as a set of dispositions that shapes people's perceptions, practices and sensibilities towards religion. ${ }^{75}$ Esra Özyürek ${ }^{76}$ has astutely shown how, in Turkey, the contrast between secularism as a state policy and discourse and secularity as a cultural orientation was revealed through the ways in which politically disempowered secular elites turned the secular into an ethics and aesthetics of personal, rather than public, life. Manifestations of secularity in public discourse and everyday life can be disconnected as well as entwined. The cultural norm not to adopt explicitly religious standpoints in a public debate may be anchored in a liberal conception of the public sphere but it may also be anchored in, and be an expression of, the reduced social significance of religion in a whole society. As a result of these observations, we make the following three propositions:

(1) The ways in which manifestations of secularity are related to one another on different social levels - legal frameworks, the public sphere, cultural habitus - are contingent.

(2) It seems more likely that one particular type of secularity becomes culturally dominant in a given society if there is some degree of cultural resonance between these different manifestations.

(3) Such cultural resonances may develop even in culturally and religiously diverse societies if different social groups are jointly invested in a 'secular settlement ${ }^{77}$, if only for divergent reasons.

By emphasising the fact that secularities emerge as cultural responses to historical problems around the management of religion, we also flag the differences between our use of the term 'model' or 'type' of secularity and the notion of 'national models' of citizenship, immigrant integration, church-state regimes or the governance of religion. Scholars participating in these debates have particularly criticised the use of such models as the independent variable to explain policy change and administrative practices around religion. They have argued that models are constantly changing ${ }^{78}$ and that they are, in fact, the result of processes of contestation and 'model-

75 Uta Karstein (2013), Konflikt um die symbolische Ordnung: Genese, Struktur und Eigensinn des religiös-weltanschaulichen Feldes in der DDR (Würzburg: ERGON).

76 Özyürek (2006), Nostalgia for the Modern.

77 Damon Mayrl (2016), Secular Conversions: Political Institutions and Religious Education in the United States and Australia, 1800-2000 (Cambridge: Cambridge University Press).

Bader (2007), Secularism or Democracy? 
ling practices ${ }^{79}$. Significantly, as Bowen ${ }^{80}$ has shown, even French laïcité as the presumably neatest and most coherent model for governing religion ${ }^{81}$, is made up of an endless series of messy, often contradictory, norms and practices, which renders the idea of laïcité as a 'national model' questionable.

While we share this criticism of the use of concepts like 'national models', we already start from the assumption that historical formations of secularity are characterised by both civilisational cultures and multiple forms of transnational cultural encounter and cross-civilisational entanglement. ${ }^{82}$ The ideal-types of secularity described above are conceptual possibilities that are not solely framed within particular national traditions. We would argue that the messiness and contradictory orientations sociologists and anthropologists often find in studies of regulatory practices around religion can be explained as expressions of competing logics of secularity that exist side by side within the same national setting. Such competing logics of secularity inspire different kinds of practices that still cohere around certain guiding ideas such as individual freedom, respect or functional autonomy.

While it is generally a complex task to decide whether one type of secularity is dominant, it is equally difficult to explain how and why certain types of secularity become dominant and hegemonic. While theories of social change broadly distinguish between incremental change and revolutionary change, in his book 'Secularism and State Policies Towards Religion: The United States, France and Turkey', Ahmet Kuru proposes the notion of critical junctures as moments that trigger shifts in historical orientations. Kuru argues that a critical juncture is a moment when both agency and conditions are available for a systematic change..$^{83} \mathrm{He}$ builds on Capoccia and Kelemen ${ }^{84}$, who conceptualised critical junctures as periods in which "choices close off alternative options and lead to the establishment of institutions that generate self-reinforcing path-dependent processes." Similarly, in his historical sociology of the secularisation of religious education poli-

79 Avi Astor (2014), "Religious Governance and the Accommodation of Islam in Contemporary Spain," Journal of Ethnic and Migration Studies 40/11: 1716-35.

80 John R. Bowen (2007), Why the French Don't Like Headscarves: Islam, the State, and Public Space (Princeton: Princeton University Press).

81 Grace Davie (2000), Religion in Modern Europe: A Memory Mutates (Oxford: Oxford University Press).

82 See also Göle (2015), Islam and Secularity.

83 Kuru (2009), Secularism and State Policies toward Religion, 27.

84 Giovanni Capoccia, and R. D. Kelemen (2007), "The Study of Critical Junctures: Theory, Narrative, and Counterfactuals in Historical Institutionalism," World Politics 59/3: 341. 
cies in the US and Australia, Damon Mayr ${ }^{85}$ argued that in both countries, in several periods, processes of religious conflict and state-building led to the negotiation of historically new 'secular settlements'. Finding that courts were central in American history, and traditional parliamentary processes in Australia, he suggests that these institutional avenues varied because "they were differently available to those political forces who were most active in defining the terms of the new settlement" (ibid., p. 158). In addition, there is a renewed interest in social mechanisms understood as the relation and causal force that produce certain outcomes in a non-accidental fashion. Gorski ${ }^{86}$ defined social mechanisms as the "emergent causal powers of entities within a system" and contrasted this concept with both the cultural interpretation that reads history as sequences of events and positivist statistical correlations that treat mechanisms and historical causality as a 'black box'.

In our view, certain types of secularity may become hegemonic in society if a particular perception and framing of the social problem secularity is meant to tackle (individual freedom, religious difference etc.) becomes hegemonic. And similarly, hegemonic types of secularity may shift in history when institutionalised framings of these problems are challenged, unmade and rearranged. Such historical shifts acquire a particular social traction and cultural force when they are condensed in guiding ideas that reorient and reinforce dynamics of secularisation. Finally, we suggest that some level of consensus about the desired outcome, whether enacted as a Gramscian hegemony or negotiated on the basis of diverging interests, increases the chances that particular types of secularity become institutionalised and culturally anchored. All of this, however, needs in-depth empirical research that is both sociological and historical nature.

85 Mayrl (2016), Secular Conversions.

86 Philip Gorski (2009), "Social 'mechanisms' and comparative-historical sociology: A critical realist proposal," in Frontiers of Sociology. Ed. Peter Hedström, and Björn Wittrock (Leiden: Brill), 189. 
Alexander, Jeffrey, and Philip Smith (2002). "The Strong Program in Cultural Theory: Elements of a Structural Hermeneutics." In Handbook of Sociological Theory. Edited by Jonathan H. Turner, 135-50. Boston, MA: Springer Science.

Árnason, Jóhann P., Shmuel N. Eisenstadt, and Björn Wittrock, eds. (2005), Axial Civilizations and World History. Leiden: Brill.

Asad, Talal (2003). Formations of the Secular: Christianity, Islam, Modernity. Edited by Mieke Bal and Hent de Vries. Stanford: Stanford University Press.

Astor, Avi (2014). "Religious Governance and the Accommodation of Islam in Contemporary Spain." Journal of Ethnic and Migration Studies 40/1: 1716-35. doi:10.1080/136 9183X.2013.871493.

Bader, Veit (2007). Secularism or Democracy? Associational Governance of Religious Diversity. Amsterdam: Amsterdam University Press.

Bader, Veit (2007). “The Governance of Islam in Europe: The Perils of Modelling." Journal of Ethnic and Migration Studies 33/6: 871-86. doi:10.1080/13691830701432723.

Berger, Peter L., ed. (1999). The Desecularization of the World: Resurgent Religion and World Politics. Washington, DC: Ethics and Public Policy Center.

Berger, Peter L., Grace Davie, and Effie Fokas, eds. (2008). Religious America, Secular Europe? A Theme and Variations. Aldershot: Ashgate.

Bowen, John R. (2007). Why the French Don't Like Headscarves: Islam, the State, and Public Space. Princeton: Princeton University Press.

Burchardt, Marian (2016). "Recalling modernity: How nationalist memories shape religious diversity in Quebec and Catalonia." Nations and Nationalism 41/4: 1-21. doi:10.1111/nana.12233.

Burchardt, Marian, and Hovhannes Hovhannisyan (2016). "Religious vs secular nationhood: 'Multiple secularities' in post-Soviet Armenia." Social Compass 63/4: 427-43. doi:10.1177/0037768616663981.

Burchardt, Marian, Monika Wohlrab-Sahr, and Matthias Middell, eds. (2015). Multiple
Secularities Beyond the West: Religion and Modernity in the Global Age. Boston: De Gruyter.

Burchardt, Marian, Monika Wohlrab-Sahr, and Ute Wegert (2013), “'Multiple Secularities': Post-colonial variations and guiding ideas in India and South Africa." International Sociology 28/6: 612-28.

Cady, Linell E., and Elizabeth S. Hurd (2010). "Comparative Secularisms and the Politics of Modernity: An Introduction.” In Comparative secularisms in a global age. Edited by Linell E. Cady, and Elizabeth S. Hurd, 3-24. New York: Palgrave Macmillan.

Capoccia, Giovanni, and R. D. Kelemen (2007). "The Study of Critical Junctures: Theory, Narrative, and Counterfactuals in Historical Institutionalism." World Politics 59/3: 341-69.

Casanova, José (1994). Public Religions in the Modern World. Chicago: University of Chicago Press.

Casanova, José (2006). "Secularization Revisited: A Reply to Talal Asad." In Powers of the Secular Modern: Talal Asad and his Interlocutors. Edited by David Scott, and Charles Hirschkind, 12-30. Stanford: Stanford University Press.

Casanova, José (2008). "Public religions revisited." In Religion: Beyond a Concept. Edited by Hent de Vries, 101-19. New York: Fordham University Press.

Casanova, José (2009. “The Secular and Secularisms." Social Research 76/4: 1049-66.

Davie, Grace (2000). Religion in Modern Europe: A Memory Mutates. Oxford: Oxford University Press.

Demerath, N. J. (2007) "Secularization and Sacralization Deconstructed and Reconstructed." In The SAGE Handbook of the Sociology of Religion. Edited by James A. Beckford, and N. J. Demerath, 57-80. Los Angeles: Sage.

Eisenstadt, Shmuel N. (1996). Japanese Civilization: A Comparative View. Chicago: University of Chicago Press.

Eisenstadt, Shmuel N. (1998). "The Construction of Collective Identities in Latin America: Beyond the European Nation-State Model." In Constructing Collective Identities 
and Shaping Public Spheres: Latin American Paths. Edited by Luis Roniger, and Mario Sznajder, 245-63. Brighton: Sussex Academic Press.

Eisenstadt, Shmuel N. (2000). "Multiple Modernities.” Daedalus 129/1: 1-29.

Eisenstadt, Shmuel N. (2002). “The First Multiple Modernities: Collective Identities, Public Spheres and Political Order in the Americas." In Globality and Multiple Modernities: Comparative North American and Latin American perspectives. Edited by Luis Roniger, and Carlos H. Waisman, 7-28. Brighton: Sussex Academic Press.

Eisenstadt, Shmuel N. (2005). "Axial civilizations and the Axial Age Reconsidered." In Axial Civilizations and World History. Edited by Jóhann P. Árnason, Shmuel N. Eisenstadt, and Björn Wittrock, 531-64. Leiden: Brill.

Esposito, John L., and Azzam Tamimi, eds. (2000). Islam and Secularism in the Middle East. London: Hurst \& Company.

Fetzer, Joel S., and J. C. Soper (2005). Muslims and the State in Britain, France, and Germany. Cambridge: Cambridge University Press.

Ganji, Akbar (2008). The Road to Democracy in Iran. Cambridge, MA, London: Boston Review Books.

Giesecke, Michael (2006). Der Buchdruck in der frühen Neuzeit: Eine historische Fallstudie über die Durchsetzung neuer Informationsund Kommunikationstechnologien. Frankfurt am Main: Suhrkamp.

Göle, Nilüfer (2015). Islam and Secularity: The Future of Europe's Public Sphere. Durham: Duke University Press.

Gorski, Philip S. (2000). "Historicizing the secularization debate: Church, state and society in late medieval and early modern Europe, ca. 1300-1700." American Sociological Review 65: 138-67.

Gorski, Philip S. (2009). “Social 'mechanisms' and comparative-historical sociology: A critical realist proposal." In Frontiers of Sociology. Edited by Peter Hedström, and Björn Wittrock, 147-94. Leiden: Brill.

Gorski, Philip S., and Ateş Altınordu (2008). "After Secularization?" Annual Review of Sociology 34/1: 55-85. doi:10.1146/annurev. soc.34.040507.134740.
Grace Davie (2000), Religion in Modern Europe: A Memory Mutates (Oxford: Oxford University Press).

Habermas, Jürgen (2006). "Religion in the Public Sphere." European Journal of Philosophy 14/1: 1-25. doi:10.1111/j.14680378.2006.00241.x.

Hjelm, Titus, ed. (2015). Is God back? Reconsidering the New Visibility of Religion. London, New York: Bloomsbury Publishing.

Inglehart, Ronald (1997). Modernization and Postmodernization: Cultural, Economic and Political Change in 43 Societies. Princeton, NJ: Princeton University Press.

Inglehart, Ronald, and Wayne E. Baker (2000). "Modernization, Cultural Change, and the Persistence of Traditional Values." American Sociological Review 65/1: 19-51.

Jacoby, Susan. Freethinkers (2004): A history of American Secularism. New York: Metropolitan Books.

Joppke, Christian (2015). The Secular State Under Siege: Religion and Politics in Europe and America. Cambridge: Polity Press.

Karstein, Uta (2013). Konflikt um die symbolische Ordnung: Genese, Struktur und Eigensinn des religiös-weltanschaulichen Feldes in der DDR. Würzburg: Ergon.

Kinitz, Daniel (2015). "Deviance as Phenomenon of Secularity: Islam and Deviants in Twentieth-century Egypt-A Search for Sociological Explanations." In Multiple Secularities Beyond the West: Religion and Modernity in the Global Age. Edited by Marian Burchardt, Monika Wohlrab-Sahr, and Matthias Middell, 97-119. Boston: De Gruyter.

Kleine, Christoph (2013). "Religion als begriffliches Konzept und soziales System im vormodernen Japan: Polythetische Klassen, semantische und funktionale Äquivalente und strukturelle Analogien." In Religion in Asien? Studien zur Anwendbarkeit des Religionsbegriffs. Edited by Peter Schalk et al., 225-92. Uppsala: Uppsala Universitet.

Kleine, Christoph (2013). "Religion and the Secular in Premodern Japan from the Viewpoint of Systems Theory." Journal of Religion in Japan 2/1: 1-34. doi:10.1163/2211834912341246.

Knöbl, Wolfgang (2007). Die Kontingenz der Moderne: Wege in Europa, Asien und 
Amerika. Frankfurt am Main, New York: Campus.

Koenig, Matthias (2007). "Europäisierung von Religionspolitik: Zur institutionellen Umwelt der Anerkennungskämpfe muslimischer Migranten." In "Konfliktfeld Islam in Europa." Edited by Monika Wohlrab-Sahr, and Levent Tezcan. Special issue, Soziale Welt 17: 347-68.

Koenig, Matthias (2015). "Governance of Religious Diversity at the European Court of Human Rights.” In International Approaches to Governing Ethnic Diversity. Edited by Jane Boulden and Will Kymlicka, 51-78. Oxford: Oxford University Press.

Kuru, Ahmet T. (2009). Secularism and State Policies toward Religion: The United States, France, and Turkey. Cambridge, New York: Cambridge University Press.

Luckmann, Thomas (1980). "Säkularisierung ein moderner Mythos." In Lebenswelt und Gesellschaft: Grundstrukturen und geschichtliche Wandlungen, 161-72. Paderborn: Ferdinand Schöningh.

Mahmood, Saba (2006). "Secularism, Hermeneutics, and Empire: The Politics of Islamic Reformation." Public Culture 18/2: 323-47.

Manzoor, Parvez S. (2000). "Descralising Secularism." In Islam and Secularism in the Middle East. Edited by John L. Esposito, and Azzam Tamimi, 81-96. London: Hurst \& Company.

Martin, David (1978). A General Theory of Secularization. Oxford: Blackwell.

Martin, David (2005). On Secularization: Towards a Revised General Theory. Aldershot: Ashgate.

Mayrl, Damon (2016). Secular Conversions: Political Institutions and Religious Education in the United States and Australia, 1800-2000. Cambridge: Cambridge University Press.

McLeod, Hugh (2007). The Religious Crisis of the 1960s. Oxford, New York: Oxford University Press.

Modood, Tariq (2010). "Moderate Secularism, Religion as Identity and Respect for Religion." The Political Quarterly 81/1: 4-14.

Navaro-Yashin, Yael (2002). Faces of the State: Secularism and Public Life in Turkey. Princeton, NJ: Princeton University Press.

Özyürek, Esra (2006). Nostalgia for the Modern: State Secularism and Everyday Politics in Turkey. Durham: Duke University Press. Raaflaub, Kurt A. (2005) "Polis, 'the Political', and Political Thought: New Departures in Ancient Greece, c. 800-500 BCE." In Axial Civilizations and World History. Edited by Jóhann P. Árnason, Shmuel N. Eisenstadt, and Björn Wittrock, 253-83. Leiden: Brill.

Schmidt-Lux, Thomas, Monika Wohlrab-Sahr, and Alexander Leistner (2016). Kultursoziologie: Eine problemorientierte Einführung. Weinheim: Beltz.

Schuh, Cora, Marian Burchardt, and Monika Wohlrab-Sahr (2012). "Contested Secularities: Religious Minorities and Secular Progressivism in the Netherlands." Journal of Religion in Europe 5: 349-83.

Schulze, Reinhard (2010). "Die Dritte Unterscheidung: Islam, Religion und Säkularität: Säkularität unter Muslimen.” In Religionen - Wahrheitsansprüche - Konflikte: Theologische Perspektiven. Edited by Walter Dietrich, and Wolfgang Lienemann, 147-206. Zürich: TVZ Theologischer Verlag.

Secor, Laura (2016). Children of Paradise: The Struggle for the Soul of Iran. New York: Riverhead Books.

Shabestari, Mohammad M., and Jan Kuhlmann (2012). "Interview with Mohammad Mojtahed Shabestari: Why Islam and Democracy Go Well Together - Qantara.de.” https:// en.qantara.de/content/interview-with-mohammad-mojtahed-shabestari-why-islamand-democracy-go-well-together, accessed 1 June, 2017.

Smith, Christian (2003). "Introduction: Rethinking the secularization of American public life." In The Secular Revolution: Power, interests, and conflict in the secularization of American public life. Edited by Christian Smith, 1-95. Berkeley: University of California Press.

Soroush, Abdolkarim (2000). Reason, Freedom, and Democracy in Islam: Essential Writings of Abdolkarim Soroush. Edited by Mahmoud Sadri, and Ahmad Sadri. Oxford: Oxford University Press.

Stark, Rodney, and Roger Finke (2000). Acts of Faith: Explaining the Human Side of Religion. Berkeley: University of California Press.

Stepan, Alfred (2000). "Religion, Democracy, and the 'Twin Tolerations.' Journal of Democracy 
11/4: 37-57.

Strauss, Anselm L. (1987). Qualitative Analysis for Social Scientists. Cambridge: Cambridge University Press.

Swidler, Ann (1986). "Culture in Action: Symbols and Strategies." American Sociological Review 51/2: 273-86.

Taylor, Charles (2007). A Secular Age. Cambridge: Belknap Press of Harvard University Press.

van der Veer, Peter (1994). Religious Nationalism: Hindus and Muslims in India. Berkeley: University of California Press.

Wagner, Peter (2001). Theorising modernity: Inescapability and Attainability in Social Theory. London: Sage.

Wagner, Peter (2005). "Palomar's Questions: The Axial Age Hypothesis, European Modernity and Historical Contingency." In Axial Civilizations and World History. Edited by Jóhann P. Árnason, Shmuel N. Eisenstadt, and Björn Wittrock, 87-106. Leiden: Brill.

Weber, Max. 'Die 'Objektivität' sozialwissenschaftlicher und sozialpolitischer Erkenntnis." In Gesammelte Aufsätze zur Wissenschaftslehre. Edited by Johannes Winckelmann, 146-214. Tübingen: Mohr.

Wittrock, Björn (2005). "Meaning of the Axial Age." In Axial Civilizations and World History. Edited by Jóhann P. Árnason, Shmuel N. Eisenstadt, and Björn Wittrock, 51-85. Leiden: Brill.

Wohlrab-Sahr, Monika (2011). "Multiple secularities and their normativity as an empirical subject: The Immanent Frame." http:// blogs.ssrc.org/tif/2011/12/13/multiplesecularities-and-their-normativity-as-anempirical-subject/, accessed 3 March, 2015.

Wohlrab-Sahr, Monika, and Marian Burchardt (2012). "Multiple Secularities: Toward a Cultural Sociology of Secular Modernities." Comparative Sociology 11/6: 875-909. doi:10.1163/15691330-12341249.

Wohlrab-Sahr, Monika, Thomas Schmidt-Lux, and Uta Karstein (2008). "Secularization as Conflict." Social Compass 55/2: 127-39. 
